\title{
Tarkastelupisteessä opintokerho
}

Lahti, Usko. 1988. Tarkastelupisteessä opintokerho. Aikuiskasvatus 8, 3. 20-22. - Artikkelissa tarkastellaan opintokerhomuotoisen aikuiskasvatustyön kehitystä ja ongelmia viimeisten vuosien aikana. Tarkastelun kohteena on opintokerhojen määrällinen kehitys ja kehitykseen johtaneet syyt. Toiseksi artikkelissa tarkastellaan sitä kuvaa, mikä opintokerhosta muodostuu vuonna 1987 tehdyn Maaseudun Sivistysliiton opinto-ohjaajille suunnatun kyselytutkimuksen välityksellä. Opintokerhotyö on kohdannut voimakkaan määrällisen laskun samalla, kun kerho työmuotona on irtoamassa perinteisistä juuristaan, yhteiskunnallisesti orientoituvista järjestöistä. Opintokerhotyössä vallitsee entistä voimakkaammin eriytyminen yhtäältä sosiaalisten organisaatioiden suuntaan ja toisaalta opinnollisesti orientoituvien vaikuttajaryhmien suuntaan. Artikkelissa asetetaan perusongelmaksi opintokerhon integroimisen mahdollisuus osaksi yhteiskuntamme laajempaa kasvatusjärjestelmää.

Kyselytutkimuksen tavoitteena oli selvittää MSL:n opintokerhojen määrällisen kehityksen syitä sekä opintokerhoissa vallitsevaa tilannetta. Selvitys jakaantui kahdeksi osaksi: määrälliseksi analyysiksi vuosilta 1976-86 sekä kerho-ohjaajille suunnatun kyselyn analyysiksi. Ohjaajat valittiin kohteiksi, koska he muodostavat rajallisen, tunnetun populaation ja heidän katsotaan heijastavan käsityksillään kerhon todellisuutta. Kyselytutkimus perustui ositettuun satunnaisotantamenetelmään. Näytteitä tuli 336 eli 11 \% määritellystä joukosta. Vastausaste oli $77,1 \%$, mitä on pidettävä vähintään tyydyttävänä. Lomakkeessa oli 36 kysymystä tai kysymyssarjaa, joista muodostettiin 105 muuttujaa. Muuttujien käsittely tapahtui Pato -tilasto-ohjelmalla.

\section{Irti yhteiskunnallisesta todellisuudesta}

Opintokerho on nähty järjestöllisen sivistystyön kulmakivenä. Sen taival on vuosikymmenien pituinen. Oleellista kerhotyölle on ollut sitoutuminen yhteiskunnallisten organisaatioiden arvolähtökohtiin. Kerholla itsellään on ollut riittävästi sisäistä evoluutiovoimaa ajantasalla pysymiseksi. Kuitenkin nyt on olemassa selviä tunnusmerkkejä, jotka pakottavat asettamaan opintokerhon kriittiseen tarkasteluun suhteessa nykypäivän yhteiskunnalliseen todellisuuteen.

Opintokerhotoiminnan määrällinen huippu saavutettiin vuonna 1984, jolloin maassamme oli kaikkiaan lähes 26000 opintokerhoa. Vuonna 1987 tuo luku oli kymmentätuhatta alempi. Kato on kohdannut hyvin voimakkaasti yhteiskunnallisissa järjestöissä tapahtuvaa kerhotyötä, näin erityisesti poliittisten järjestö- jen parissa. Eläkeläisjärjestöissä ei sen sijaan samankaltaista laskua ole havaittavissa.

Ilmeistä on, että opintokerhotyö ja poliittisten järjestöjen toimintaperiaatteet ovat ajautuneet erilleen toisistaan, yhteistä tekijää ei enää löydetä. Eläkeläisjärjestöjen suhteellisen osuuden kasvu selittynee parhaiten eläkeläisten yleisen aktivoitumisen avulla, opintokerhokin on saanut osuutensa tästä noususta.

Usein väitetään, että opintokerhotyöhön liittyvä pakollinen hallintobyrokratia olisi kriisin todellinen syy. Se ei kuitenkaan yksin riitä selittämään vaikeuksia. Oleellisempaa sittenkin on nähdä opintokerhoajatuksen pysähtyneisyys verrattuna sitä ympäröivän yhteiskunnan kehittymiseen. Lyhyesti sanottuna suhteessa yhteiskunnalliseen kehitykseen opintokerho on pysynyt paikoillaan ja jopa ottanut takaaskeliakin.

Lopultakaan opintokerhojen lukumäärä ei ole oikea kriteeri mittaamaan opintokerhon tilaa. Voimakas määrän lasku kertoo kuitenkin selkeästi, että opintokerho on kohdannut vaikeuksia, joiden tulisi viimeistään nyt herättää asiaan tavalla tai toisella vihkiytyneet.

\section{Ohjaajan muotokuva}

Opintokerhon opinto-ohjaajan tehtävänä on vastata omaehtoisen pienryhmän toimivuudesta. Hän vastaa ryhmän sosiaalisesta toimivuudesta, mutta hänen tulee kantaa myös vastuuta ryhmän opiskelun tasosta ja opintokerhon muodollisesta puolesta - valtionapuhallinnosta.

Nykyisille ohjaajille on tyypillistä se, että peräti kolme neljäsosaa heistä on naisia ja 
heidän keski-ikänsä on ollut nousussa. Tyypillistä on myös se, että keski-iän nousun myötä ohjaajien peruskoulutustaso on ollut alenemaan päin.

Opintokerhoissa vallitsee kaksi ikärakennemallia: ensinnäkin ohjaaja on muita kerhon jäseniä selvästi iäkkäämpi - hänellä on auktoriteettiasema - ja toiseksi ohjaaja ja muut kerhon jäsenet ovat kutakuinkin samanikäisiä - ohjaajalla on vertaisasema. Ohjaajan iän perusteella syntyvä auktoriteettiasema ei sinänsä vastaa kysymykseen ohjaajan aseman kehittämisestä, sen syntytausta ei ole välttämättä opinnollisissa lähteissä.

Mielenkiintoista on, että vain ikä ja siihen voimakkaasti kietoutuva peruskoulutustaso selittävät yhdessä eroja ohjaajien kerhonäkemyksissä. Sen sijaan sukupuoli tai asuinpaikka eivät omaa vastaavaa selitysvoimaa toisin kuin aikaisemmin on oletettu.

\section{Opintokerhon tarkoitus}

Selvityksen mukaan on olemassa kaksi päänäkemystä opintokerhon tarkoituksesta: ensinnäkin opintokerho on yhdessäolo-organisaatio ja toiseksi opintokerho on opinnollisesti orientoituva vaikuttajaryhmä. Nämä päänäkemykset ovat luonteeltaan toisiaan hylkiviä.

Tärkeimmiksi tarkoitusperiksi selvityksen mukaan nousee kerhon jäsenten yhdessäolon ja viihtyvyyden edistäminen. Opintokerholla nähdään tällöin olevan sosiaalinen funktio.

Toisen tarkoitusryväksen - toisen päänäkemyksen - muodostavat kerhon jäsenten tietojen ja taitojen lisääminen eli opinnollinen funktio, järjestötyön kehittäminen eli toiminnallinen funktio sekä poliittinen vaikuttaminen eli vaikutusfunktio. Suosituin näistä osanäkemyksistä on ehdottomasti ensimmäiseksi mainittu.

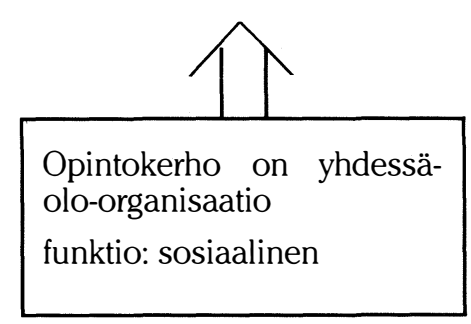

$$
\begin{aligned}
& \text { Opintokerho on opinnolli- } \\
& \text { sesti orientoituva vaikuttaja- } \\
& \text { ryhmä } \\
& \text { funktiot: opinnollinen } \\
& \text { toiminnallinen } \\
& \text { vaikutuksellinen }
\end{aligned}
$$

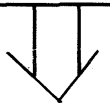

Näkemyksien omaksumista ohjaavat selvästi ihmisen elämänkaaren pituus ja siihen liittyvät koulutus ja elämänkokemukset. Mitä iäkkäämpi ihminen on, sitä todennäköisemmin hän etsii opintokerhosta viihtyvyyttä, ihmissuhteita ja sosiaalista kanssakäymistä. Ja kääntäen; mitä nuorempi ihminen on, sitä todennäköisemmin hän puolestaan etsii opintokerhosta ulospäin suuntautuvaa aktiivisuutta sekä uusia tietoja ja taitoja itselleen.

Huolestuttavin piirre tarkoitusnäkemysten kannalta on se, että päänäkemykset korreloivat negatiivisesti toisiinsa. Syystä tai toisesta sosiaalisuus ja opinnollisuus eivät mahdu samaan opintokerhoon.

\section{Osallistumisen esteet}

Opintokerhotyöhön osallistumisen suurin este on kilpailu ihmisten vapaa-ajasta. Myös kulkuyhteyksien puutteellisuus sekä koti ja perhe koetaan todellisiksi esteiksi. Opintokerhoon itseensä liittyvät haittatekijät ovat esteinä sen sijaan suhteellisen vähäisiä. Esimerkiksi valtionapubyrokratiaa ei sellaisenaan pidetä ratkaisevana osallistumisesteenä.

Esteet ovat nekin sidoksissa ikätekijään. Luonnollista on, että iän noustessa nousee kulkuyhteyksien puute esteeksi. Yhtä luonnollista on, että nuorten aikuisten kohdalla muut harrastukset sekä koti ja perhe estävät osallistumista opintokerhotyöhön.

Merkittävä havainto toisaalta on, että aktiivisessa työiässä ei aikaa liikene sittenkään opintokerho-opiskeluun, vaikka vapaa-aika on sinänsä lisääntymässä. Entä sitten, kun tämän päivän nuoret aikuiset tulevat kypsempään ikään, riittääkö heiltä silloin aikaa opintokerholle?

\section{Monipuolisuutta menetelmuin}

Suosituin opiskelumenetelmä opintokerhoissa on keskustelu ryhmissä. Tämä osoittaa myönteistä ja sosiaalista ilmapiiriä kerhoyhteisöissä. Sen sijaan uudehkot menetelmät - kuten radion, television tai elokuvan käyttö - saavat vielä odottaa vuoroaan.

Varsinkin iäkkäiden opiskelijoiden opintokerhoissa vallitsee yleisesti eräänlainen lukupiirimenetelmä. Tämän menetelmän mukaisesti yksi kerhonjäsen - useimmiten ohjaaja - lukee jakson opiskelun kohteena olevaa oppikirjaa tai muuta tietolähdettä, jonka jälkeen kerho käy keskustelun kuullun perusteella.

Lukupiiri on sinänsä käyttökelpoinen menetelmä, mutta siihen liittyy valitettavasti se tosiasia, että tällaiset opintokerhot ovat jäsenmäärältään keskimääräistä suurempia ja niissä käytettävien kirjallisten opintoaineistojen lukumäärä opiskelijaa kohti on suhteellisen pieni, 
jopa äärimmäisen alhainen. Pahimmillaan lukupiiri saattaa siten muuttua passivoittavaksi tekijäksi.

Opintokerhoissa olisi varaa lisätä harjoittelun ja kotitehtävien osuutta menetelminä. Nämä menetelmät toisivat mukanaan jatkuvuutta ja omakohtaista kokemista työskentelyyn. Toisaalta opintokerho voisi puolestaan olla osa jotakin laajempaa opinnollista prosessia, sen syventyvä harjoitteluosa.

\section{Kohti ohjaajalaitosta?}

Opintokerhon oppimisprosessin onnistuminen lepää pitkälti ohjaajan taitojen varassa. Peruskysymys on, missä määrin ohjaamisvastuuta keskitetään yhdelle kerhon jäsenelle ja missä määrin sitä voidaan jakaa jäsenten kesken. Ensimmäisessä tapauksessa lähestytään "ammattimaisuutta" ja toisessa taas vertaisohjaamista. Ohjaajien itsensä käsitykset tässä kysymyksessä ovat vielä sangen selkeytymättömiä ja ristiriitaisia.

Kerhon tavoite voi siten olla perusta, josta ohjaajakäsitystä tulee kehittää. Mikäli kerhon tavoitteena on oppimisen edistäminen, korostuu ohjaajan asema ryhmän pedagogisena johtajana. Mikäli kerholla on taas sosiaalisia tavoitteita, korostuu ohjaajan rooli yhdessäolojohtajana.

Jos opintokerholle asetetaan entistä selvemmin opinnollisia tavoitteita ja jos samaan aikaan yhteiskunnan antama taloudellinen tuki kerholle lisääntyy, on ajateltava jopa "ammattimaisen" ohjaajalaitoksen luomista. Tämä ratkaisu nostaisi opintokerhojen opinnollista tasoa ja takaisi taloudellisen tehokkuuden sekä ennen muuta antaisi motivaatioperustan ohjaajan työlle.

Opintokerhotyön kehittäminen edellyttää, että entistä ponnekkaammin tuetaan korotetun valtionavun opintokerhojen työskentelymahdollisuuksia ja annetaan nimenomaan ohjaajille mahdollisuus kehittyä niin halutessaan "ammattimaiseen" suuntaan. Tämä puolestaan edellyttää valtionavun merkittävää korottamista näille kerhoille. Tämä ei kuitenkaan saa merkitä sitä, että perusvaltionavun opintokerho unohdettaisiin kehitystyössä, mutta voimavaroja on löydyttävä uuteenkin kehittelyyn.

\section{Tosiasioiden edessä}

Opintokerhon tulevaisuutta ajatellen olemme väistämättä muutaman ohittamattoman tosiasian edessä.

Ensiksikin on selvää, että opintokerhonäkemykset ovat eriytyneet kahdeksi päänäkemykseksi. Jos opintokerhoa halutaan todella kehittää, on tämä tosiasia muistettava kaikessa kerhotyömuodolle suunnattavassa palvelussa. Sosiaalisesti orientoituville opintokerhoille tulee tuottaa palveluita, jotka sisältävät laaja-alaisia, elämään sellaisenaan liittyviä oppiaineksia spesifisten ainesten sijasta. Opinnollisesti orientoituville vaikuttajaryhmille voidaan sen sijaan tuottaa spesifisiä aineksia sisältäviä palveluita.

Toiseksi opintokerhotyö on saanut vastakaikua ikääntyvän aikuisväestön osallistumismuotona. Palveluita luotaessa on siten otettava aikaisempaa tietoisemmin huomioon ihmisen ikä, on ymmärrettävä oppimisen ongelmat ja edut eri ikäkausina.

Kolmanneksi opintokerhojen yhteenlaskettu lukumäärä on kiistatta asettunut huippulukemien alapuolelle, eikä lukumäärää pidäkään kasvattaa panostamalla valtionapua sinne, missä lukumäärä saattaisi helpoiten nousta. Väärä panostuksen suunta johtaisi kerhotoiminnan jälleen uuteen uskottavuuskriisiin ja kenties lopulliseen turmioon.

Onkin aika etsiä ennakkoluulottomasti ratkaisuja, joiden avulla opintokerho voisi toimia siltana virallisen ja vapaan kasvatusjärjestelmän välillä yhtä lailla kuin siltana ihmisen eri ikäkausien välilläkin. Panostuksen tulee siten kohdistua sisältöön, ei kerhomäärän kasvattamiseen.

\section{Takaisin yhteiskuntaan}

Perinteisenä aikuisopiskelumuotona opintokerholla on tietenkin oma itseisarvonsa, mutta senkin tulee sopeutua yhteiskunnallisiin muutoksiin. Opintokerho on ollut omalta osaltaan vastaamassa yhteiskunnassa heränneisiin kasvatustarpeisiin, entä nyt? Kasvatustarpeetkin ovat muuttuva suure ja vain sellainen liike, joka aistii ennakolta muutokset, pystyy sopeutumaan niihin ja pystyy sen lisäksi vastaamaan tarpeisiin, voi elää.

Jos opintokerho hyväksytään osaksi laajempaa yhteiskunnallista muutosta ja yhteiskuntaan rakennettua aikuiskasvatusjärjestelmää, sitä voidaan sisällöllisesti kehittää ja antaa sille jopa muodollinen asema järjestelmässä. Samalla on kuitenkin huolehdittava opintokerhon perusolemuksen säilymisestä, kansanvaltaisesta itseohjautuvuudesta. Nämä vaatimukset eivät ole keskenään ristiriidassa, ne pikemminkin tukevat toinen toistaan.

\section{Lähteet}

Alanen, A. 1970. Edistävä ja viihdyttävä opintokerhotoiminta. Acta Universitatis Temperensis, Ser. A. Vol. 29. Myllykoski.

Alanen, A. 1986. Sivistysjärjestöjen tehtäväkuvien muuttuminen. Aikuis- ja nuorisokasvatuksen laitoksen julkaisuja, Tampereen yliopisto. Tampere.

Karjalainen, E. - Toiviainen, T. 1984. Suomen vapaan kansansivistystyön vaiheet. Tapiola.

Lahti, U. 1987. Opintokerho muuttuvissa olosuhteissa. Maaseudun Sivistysliiton tutkimus. Helsinki. Maaseudun Sivistysliitto. 1976-1986. Vuosikerto- 
Lahti, Usko. 1988. Focus on Study Circles.

The article deals with the development and problems encountered during the recent years in the study circle type of adult education. The author looks into the quantitative development of study circles and the reasons underlying this development. Secondly, the article examines the picture formed of study circles as the result of the questionnaire study directed in 1987 at study leaders employed by The Union for Rural Education. Study circle activity has undergone a radical slump and, at the same time, study circles as a type of activity are breaking away from their traditional roots, from socially oriented organizations. Unprecedented specialization dominates study circle activity; on the one hand, in direction of scholastically oriented influential groups. The main problem, according to the author, is how to integrate study circles into the more general education system. 